\title{
An Integrative Environmental Framework for a Better Enterprise Resource Planning Post-Implementation Success
}

\author{
1Ehsan Kish Hazrat Soltan
}

\author{
${ }^{2}$ Ahmad Jusoh \\ 3Mahdi Mohammad Bagheri \\ 1, 2 Faculty of Management, Universiti Teknologi Malaysia, 81310, Johor Bahru, Malaysia \\ 3Management Department, Anar Islamic Azad University, Anar, Kerman, Iran; Khsehsan2@live.utm.my
}

Doi:10.5901/mjss.2015.v6n6p153

\begin{abstract}
The objective of research paper is to introduce a conceptual model to better define environmental Critical Success Factors (CSFs) for Enterprise Resource Planning (ERP) post-implementation stage based on the Technological, Organizational and Environmental (TOE) framework. In addition, the paper adds to existing literature the CSF of external trust with customers and suppliers, which few studies have done. The previous studies and their theoretical and conceptual frameworks are developed to demonstrate a new conceptual environmental framework that embodies CSFs that empirically related to the ERP PostImplementation Success (PIS), and add new approaches into impacts of the external trust factor on the PIS of ERP. The paper introduced a missed place of research depicting the impact of external trust on PIS of ERP and as well a shortage of a better holistic conceptual framework structured to discuss the impact of external pressures and external consultant support on PIS of ERP.
\end{abstract}

Keywords: External trust, External pressure, External consultant support, Critical success factors, TOE theory

\section{Introduction}

Enterprise Resource Planning (ERP) is a package of applications that integrate all connecting parts of the organization i.e. production, marketing, human resource etc. In order to link front-office activities as well as back-office activities inhouse and external supply chain operations (Yang and Su, 2009). However, after a decade of ERP implementation, many companies have failed to achieve the benefits expected from their ERP programs (Shao et al., 2012). In the study by Panorama (ERP Consultation Company) in (2014), during the four years of research, ERP cost 6.5 million dollars and 16.1 months in average. Across this step, approximately 50 percent of projects have implemented ERP by the planned budgets, near 28 percent of projects have implemented ERP on their planned time and finally 66 percent of organizations cached less than 50 percent of predetermined benefits of their ERP. Furthermore, researchers have focused mostly on the pre-implementation and implementation phases of the ERP while the post-implementation stage of ERP has been neglected (Grabski et al., 2011). Few researchers have focused on post-implementation procedures and their effect within an organization (Law et al., 2010; Wilson, 2012). Lack of research related to this phase of the life cycle of the ERP is the main motivation for this study. In other words, studies on (ERP) are many, but few of them have dealt with the postimplementation phase (Shao et al., 2012).

The interrelationship between the organization and its related parts is necessary for businesses to build up dynamic interaction with the environment, customers, suppliers (Wilson, 2012). Furthermore, a complete view of the interrelationships existing between organizations, technology and the environment is necessary when considering the efficiencies and effectiveness of ERP (Paradice, 2009; Wilson, 2012). Thus, in an attempt to close this gap this study would investigate the effect of external trust of customers and suppliers to the ERP that could assure the success of ERP in post-implementation phase in order to achieve predicted benefits of ERP. To address this objective, this study used the TOE theory which has been used in several studies to examine the pre-implementation and implementation of several IS applications, such as ERP e.g. (Bradford and Florin, 2003; Zhu and Kraemer, 2005; Zhu et al., 2010). Some researchers have stressed the relevance of contingency factors i.e., organizational, technological, and external environment for ERP implementation and benefit realization (Kouki et al., 2007; Kouki et al., 2010; Schniederjans and Yadav, 2013). The TOE framework integration proposes that multiple organizational factors will affect the ERP post-implementation success. 
Therefore, the TOE framework as a suitable theoretical support recognizes the possible antecedents, which could make effect on the post-implementation success. Therefore, through exhaustive review of previous studies, all the ERP CSFs in post-implementation stage covered under the external environment factors have been categorized into three factors namely: ERP external pressure, ERP external consultant support and external trust, in which most of their relationships with post-implementation success have not been empirically examined so far.

\section{Theoretical Foundations}

To examine and support the relationships existing between critical success factors and ERP post-implementation success, some underlying theories are used including: Institutional theory, attribution theory, Resource Based View (RBV), Social Capital Theory (SCT), and Technological, Organizational and Environmental (TOE) theory. In the following section these definitions will be briefly explained, and their support for their underlying relationship will be further discussed in the propositions.

\subsection{Resource Based View (RBV)}

Resource Based View (RBV) proposes that for companies to reinforce competitive advantage they must develop internal capabilities (Barney, 1996). Companies' particular capabilities as well as human and organizational resources make the difference between a company's success or failure (Peng et al., 2009). With the purpose of achieving competitive advantage companies will make use of whatever resources are available; however this is mostly pressurized by some competitive and institutional motivators. Whereas there are many motivators and driver by competitors, leading organizations, authoritarian agencies and governmental bodies to adopt, implement and use of ERP, companies mostly interested in employing internal resources, drivers and capabilities to force the success of ERP in post-implementation stage. Therefore, this study open new window to RBV theory by focus on external resources to shift and motivate success on PIS of ERP.

\subsection{Social Capital Theory}

Social Capital Theory (SCT) discusses about wide range of social resources and capital across the firms i.e., detection of the relationships network characteristics, obligations, joint benefits and ideals between individuals, sharing the knowledge as well as trust (Nahapiet and Ghoshal, 1998; Carey and Lawson, 2011). Social capitals such as ideals, values, joint benefits and sharing he knowledge are mostly preserved from extinction by in charge management (Maak, 2007), which can include both top management and overall commitment. Trust as a social capital component has significant effect on PIS of ERP and has similar effect like an organizational culture of firms that has protective and supportive effect on the performance of projects. The PIS of ERP project is more possible to occur while customers and suppliers as impressive social capitals have trust in ERP, in compare with the time that internal and external stakeholders are exhausted of any aspect in the ERP implementation community. High level of trust through the all level of operation, management and the social capital resources promote the possibility of ERP post-implementation success.

\subsection{Attribution Theory}

Attribution theory is based on how people recognize events and its relationships to their behavior and thinking. According to attribution theory, people attempt to analyze why and what other people do, and may attribute one or more causes to that behavior. A person's internal attribution is acting in a convincing way because of some characteristics about the person i.e., attitude, character or personality, while external attribution draws the conclusion that a person is acting in a certain way because of some characteristics about the condition he or she is in (Heider, 2013). When something seems problematic in facing with the system such ERP, internal and external stakeholders might refer all failure point to the system itself, somewhat to their personal operation. Heider (2013) propose that the trust of the customers and suppliers to the organization and an ERP program is through the entire life cycle of ERP and not only during implementation stage. If an ERP is not understood by an organization, trust also can be reduced (Heider, 2013). If something is understood to be mistaken with the ERP, suppliers or customers might attribute it to the ERP itself or the operation of the system, therefore losing their trust. 


\subsection{Institutional Theory}

Institutional theory suggests that institutional environments influence the organizations' actions and structure, while to promote their efficiency organizations must also legitimize themselves in their external environment in order to make decisions (DiMaggio and Powell, 1983; Scott, 2008). Institutional theory claims that institutionalization occurs when organizations encounter many pressures i.e., competing for resources, customers, political power, social and economic fitness, which try to push them to be in line with their environment (DiMaggio and Powell, 1983; Teo et al., 2003). Institutional theory demonstrates that not only the desire for efficiency but also the company's need to legitimize itself in its external environment influence structural change within the company (Benders et al., 2006). Using the institutional theory would further enrich the model and help investigate the external forces which would encourage or hold back ERP post-implementation activities.

\subsection{TOE Theory}

Technological factor in TOE theory considers the importance of technological insight in both internal and external perspective also useful in promoting organizational output (Tornatzky et al., 1990). These technologies contain various phases of the information system (IS), from foundation capabilities to the compatibility related to the organization. These technical characteristics will ease the foundation for the realization of benefits for the organization. Technological factors are introduced as a powerful predictor in the pre-implementation or post-implementation ERP (Chwelos et al., 2001; Zhu and Kraemer, 2005).

Organizational factors are the resources existing to support and maintain the acceptance and success of the system. These factor are include company managerial structure and size, as well as delicate characteristics of the organization i.e., organizational readiness to support the arrangement and a well atmosphere to use system such as ERP (Tornatzky et al., 1990; Chau and Tam, 1997). Organization has to prepare an optimistic circumstance for the system to implement effectively; hence organizational activities are vital for the ERP to promote businesses.

The environmental factors involve that the organizations external environment could influence the postimplementation process of the system through the central organization. Because implementing ERP within the entire organization is a complex function, the operation process of ERP requires in-depth information the ERP implemented organization may not have i.e., knowledge. By the way, organizations are influenced by their related industries, its competitors, and the ability of the firms to obtain the resources that supplied by others.

Table 1: Constructs, supporting theory and literature

\begin{tabular}{|l|l|l|l|l|}
\hline$\#$ & Key & Construct & Theory & Supporting Literature \\
\hline 1 & EEP & $\begin{array}{l}\text { ERP External } \\
\text { Pressure }\end{array}$ & $\begin{array}{l}\text { Institutional theory, } \\
\text { resource based view, } \\
\text { TOE theory }\end{array}$ & $\begin{array}{l}\text { Pan and Jang (2008);Zhu and Kraemer (2005); Zhu (2004);Zhu et al. (2004); } \\
\text { Zhu et al. (2003); (Kouki et al., 2007; Kouki et al., 2010); Nejib (2013); } \\
\text { Schniederjans and Yadav (2013); Shaul and Tauber (2013) }\end{array}$ \\
\hline 2 & EECS & $\begin{array}{l}\text { ERP External } \\
\text { Consultants } \\
\text { Support }\end{array}$ & $\begin{array}{l}\text { Institutional theory, } \\
\text { TOE theory }\end{array}$ & $\begin{array}{l}\text { Somers and Nelson (2004); (Kouki et al., 2007; Kouki et al., 2010); White } \\
\text { (2008); Kronbichler et al. (2009); Zhu et al. (2010); Shaul and Tauber (2013); } \\
\text { Ononiwu (2013); Nejib (2013); Schniederjans and Yadav (2013) }\end{array}$ \\
\hline 3 & EET & $\begin{array}{l}\text { ERP External } \\
\text { Trust }\end{array}$ & $\begin{array}{l}\text { Social capital theory, } \\
\text { attribution theory, TOE } \\
\text { theory }\end{array}$ & $\begin{array}{l}\text { Gefen (2004); Amoako-Gyampah and Salam (2004); White (2008); Abdullah } \\
\text { (2009); Supramaniam and Kuppusamy (2011); Upadhyay et al. (2011); Basu } \\
\text { and Lederer (2011);Schniederjans and Yadav (2013) }\end{array}$ \\
\hline
\end{tabular}

\section{Literature Review}

\section{ERP Post-Implementation Success}

With regards to life cycle theory, ERP studies have been organized into a series of phases including preimplementation, implementation, and post-implementation. Studies often gage ERP achievement by comparing it with scheduled time and/or planned budget, with lost consideration that create business value and enhance competitive advantage are the ideal achievements of using ERP. The successful deployment and use of ERP in implementation stage can have a reverse effect on the survival and performance of businesses (Markus et al., 2000). Hence, in order to enhance business performance and to create business value, implementation of the ERP projects should be considered as a continuous process (Hillman Willis and Hillary Willis-Brown, 2002; Esteves, 2009; Kouki et al., 2010). Thus, the implementation of the ERP transitions the project into the post-implementation stage (Markus et al., 2000). However, 
while few researchers have reported on the long-term issues that occur in the post-implementation phase of ERP(Worrell, 2008), previous successes have shown that the system must be enhanced in the post-implementation phase to maximize its value, ultimately creating competitive advantage for the organization (Law et al., 2010; Wilson, 2012).

Previous studies indicate that when the ERP is implemented successfully, it does not mean that the ERP in postimplementation stages is also successful because ERP includes the implementation phase and if the postimplementation phase is not successful it cannot considered successful overall (Al-Mashari et al., 2003). As long as, success on implementation of ERP may be calculated via the ERP implementation cost and budget contained by the time schedule (Yusuf et al., 2004). However, success in ERP post-implementation is explained by many criteria i.e., organizational performance and the operational performance(Sedera and Gable, 2004; Ifinedo et al., 2010). At the postimplementation phase, organizations mainly focus on the effective use of ERP in order to obtain benefits from the deployed ERP and optimize the PIS of ERP (Al-Mashari et al., 2003; Zhu et al., 2010).

ERP Benefits in Post-Implementation Phase

This study analysis ERP benefits of Shang and Seddon (2003) framework by collecting literatures concerning ERP implementation and post-implementation success between 2003 and 2013. It is not rational to study and use all the ERP benefits listed in the literature in a short period of time while the most significant ones will be considered to provide insights for both scholars and practitioners. These benefits are multidimensional, meaning that some are tangible and some others are intangible. ERP benefits could be classified into operational, managerial, strategic, IT infrastructure and organizational (Shang and Seddon, 2003; Raymond et al., 2006). (Table 2)

Operational Benefits (OP)

Operational benefits include routine and daily activities including obtaining and using resources which are typically repeated from time to time i.e. daily, weekly and monthly. ERP system mechanizes and unifies business processes and enables process changes which could be likely to present tangible benefits such as cost reduction, cycle time reduction, productivity improvement, quality improvement and improved customer service.

Managerial Benefits (MB)

ERP as an enterprise system prepares managerial benefits which are mostly intangible and include business management actions including distribution and organize of the companies' capitals, supervising and supporting of operations business in critical times in order to take strategic decisions.

Strategic Benefits (SB)

Strategic activities are related to high-level of decisions and engaged with planning in long-period of time, such as business integration and achievement, production planning, market competition, customer intention and investment sourcing. Enterprise resource planning, with huge intention to business involvement and incorporation internal/external capacities, has the ability to support the attainment of the strategic benefits i.e., business growth, alliance, innovation, cost, isolation and external relations (Pine, 1993; Victor and Boynton, 1998).

IT Infrastructure Benefits (IT)

IT infrastructure is defined as an underpinning IT resources for all information technology business applications these days (Davenport and Linder, 1994). With integrated and standard application architecture, enterprise resource planning system provides an infrastructure to reduce costs of IT and business, promote ability to on-time/budget implementation of new structures and business flexibility for future changes.

Organizational Benefits (OR)

Implementation of an ERP system results in organization focus, unity, learning and implementation of its selected strategies. Organizational benefits is consists of enhancement of a mutual mental picture about upcoming of the organization as well as promote communication between employees, which improves shared perceptive. Enterprise resource planning system creates organizational benefits i.e., promoted job patterns, powerful organizational learning, empowered employees, and a superior logic of shared perceptive across the organization.

Table 2: ERP Benefits in Post-Implementation Phase

\begin{tabular}{|c|l|l|c|c|c|c|c|}
\hline \multirow{2}{*}{$\#$} & \multirow{2}{*}{ Reference } & \multirow{2}{*}{ Implementation phase } & \multicolumn{4}{|c|}{ Benefits used in the survey } \\
\cline { 5 - 8 } & & OP & MB & SB & IT & OR \\
\hline 1 & Nejib (2013) & Post-implementation & $\sqrt{ }$ & $\sqrt{ }$ & & & \\
\hline 2 & Shao et al. (2012) & Post-implementation & $\sqrt{ }$ & $\sqrt{ }$ & & & \\
\hline 3 & Zhu et al. (2010) & Post-implementation & $\sqrt{ }$ & $\sqrt{ }$ & & & \\
\hline 4 & Kouki et al. (2010) & Post-implementation & $\sqrt{ }$ & $\sqrt{ }$ & & & \\
\hline 5 & Esteves (2009) & Post-implementation & $\sqrt{ }$ & $\sqrt{ }$ & & $\sqrt{ }$ & \\
\hline
\end{tabular}




\begin{tabular}{|c|l|l|l|l|l|c|c|}
\hline 6 & Kamhawi (2008) & Post-implementation & $\sqrt{ }$ & $\sqrt{ }$ & & $\sqrt{ }$ & \\
\hline 7 & Annamalai and Ramayah (2011) & Implementation & $\sqrt{ }$ & $\sqrt{ }$ & $\sqrt{ }$ & $\sqrt{ }$ & $\sqrt{ }$ \\
\hline 8 & Katerrattanakul et al. (2006) & Implementation & $\sqrt{ }$ & $\sqrt{ }$ & & $\sqrt{ }$ & \\
\hline 9 & Spathis and Ananiadis (2005) & Implementation & $\sqrt{ }$ & $\sqrt{ }$ & & $\sqrt{ }$ & \\
\hline 10 & Shang and Seddon (2003) & Implementation & $\sqrt{ }$ & $\sqrt{ }$ & $\sqrt{ }$ & $\sqrt{ }$ & $\sqrt{ }$ \\
\hline
\end{tabular}

Based on the comparison presented in Table 2, operational and managerial benefits are in particular more related to the post-implementation stage as confirmed by the literature (Kouki et al., 2010; Zhu et al., 2010; Shao et al., 2012; Nejib, 2013). Therefore, strategic, organizational and the IT infrastructure benefit eliminated from this study based on result of previous study because they are not a good predictor of the post-implementation success of ERP. Strategic activities are involved continuing planning, advanced decisions and strategic competitive advantage such as business growth and the business innovation that the company obtained over a period of time. This competitive advantage can be affected by other sources i.e., business strategy and market environment etc. Hence, it is more difficult to distinguish between strategic benefits of an ERP system, especially in post-implementation phase, from those of other sources. Furthermore, organizational benefits are result of the improvement in employees' image about outlook of the organization and better communication that improves understanding of employees by facilitating business learning, building common vision and empowerment. Hence, organizational benefits represent the ongoing gains of the organization over time, and therefore cannot refer only to organizational benefits of the ERP especially in post-implementation phase. Construction of a good infrastructure is an essential managerial intention in every IT project to increase IT infrastructure capacity.

\section{ERP Critical Success Factors}

Environmental factors in (TOE) framework are important as much as the technological and organizational factors. External factors refer to all external factors that affect the success of an ERP implementation. In this research paper by exhaustive review of the literature on ERP post-implementation success and CSFs related to this post-implementation stage, ERP external pressures, ERP external consultant support and external trust are considered as three dimensions that cover external factors of environmental aspect of TOE framework on ERP post-implementation success. The results are presented in Table 3.

Table 3: Critical success factors

\begin{tabular}{|c|c|c|c|}
\hline CSFs & & & \\
\hline References & 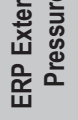 & 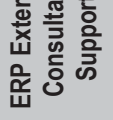 & 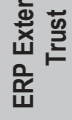 \\
\hline Parr and Shanks (2000) & & $\sqrt{ }$ & \\
\hline Somers and Nelson (2001) & & $\sqrt{ }$ & \\
\hline Shanks et al. (2001) & & $\sqrt{ }$ & \\
\hline Somer and Nelson (2004) & & $\sqrt{ }$ & \\
\hline (Kouki et al., 2007; Kouki et al., 2010) & $\sqrt{ }$ & $\sqrt{ }$ & \\
\hline White (2008) & & $\sqrt{ }$ & $\sqrt{ }$ \\
\hline Kronbichler et al. (2009) & & $\sqrt{ }$ & \\
\hline Zhu et al. (2010) & $\sqrt{ }$ & $\sqrt{ }$ & \\
\hline Nejib (2013) & $\sqrt{ }$ & $\sqrt{ }$ & \\
\hline Schniederjans and Yadav (2013) & $\sqrt{ }$ & $\sqrt{ }$ & $\sqrt{ }$ \\
\hline Abdullah (2009) & & & $\sqrt{ }$ \\
\hline Shaul and Tauber (2013) & $\sqrt{ }$ & $\sqrt{ }$ & \\
\hline Ononiwu (2013); Tarhini et al. (2015) & & $\sqrt{ }$ & \\
\hline Tarhini et al. (2015) & $\sqrt{ }$ & $\sqrt{ }$ & $\sqrt{ }$ \\
\hline Sum & 6 & 13 & 4 \\
\hline
\end{tabular}

\section{Developed Conceptual Model and Propositions}

The conceptual framework illustrated ERP external factors refer to all the external resources that affected the successful post-implementation of ERP. As a result, subsequent propositions are suggested by this study for future research to investigate.

P1: ERP external pressure has positive effect on ERP post-implementation success. 
P2: ERP external consultants have positive effect on ERP post-implementation success.

P3: ERP external trust has positive effect on ERP post-implementation success.

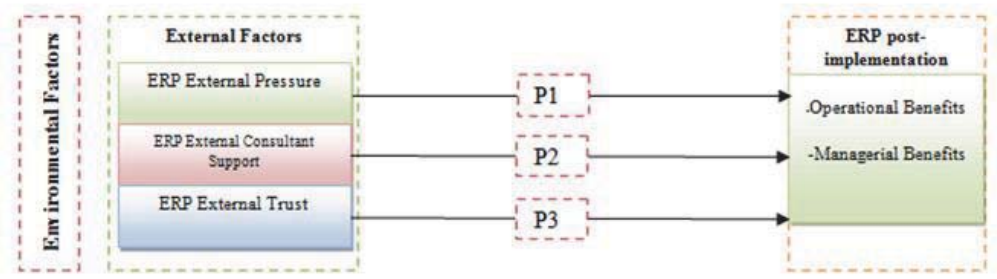

Figure 1: Research model.

\section{ERP External Pressure Influence PIS of ERP}

Institutional theory proposes that institutional environment influences organizations, therefore, to promote productivity and legitimize organizations in their institutional surroundings, vital decisions must be made (DiMaggio and Powell, 1983; DiMaggio, 1988). Institutional theory claims that institutionalization occurs when organizations encounter many pressures i.e., competing for resources, customers, political power, social and economic fitness, which try to push them to be in line with their environment (DiMaggio and Powell, 1983; Teo et al., 2003). Teo et al. (2003) describe these pressures as coercive, mimetic, and normative. Coercive pressures deployed by organizations, which are resource leading (leading suppliers and customers), authoritarian agencies, and governmental segments. Mimetic pressures defined as companies' reaction to ambiguity by emulating the other organizations decisions (mostly the headmost competitor) which, is considered as the optimum decisions (Teo et al., 2003). Normative pressures straight or ultimately press the company to set in to the system and are outcome of proficient communities and proficient standards. Mimetic and coercive pressures could use as leverage to improve the acceptance of new process and functions to cover critical decisions in companies through post-implementation stage of ERP. Normative pressure ignored by ERP because this kind of pressure intend to appear through ERP user communities, professional agencies, conferences and other professional events that is not matched with solstitial nature of ERP.

Furthermore, based on resource based theory, in the time that there is enough competitive and institutional pressure to implement the ERP, companies are expected to apply more internal capabilities to successfully drive the ERP in post-implementation stage and mostly forget to take account external drivers and motivators to increase or decrease their performance indicators i.e., ERP operational and managerial benefits. Therefore, this study intends to investigate the following:

P1: ERP external pressure has positive effect on ERP post-implementation success.

ERP External Consultant Support Influence PIS of ERP

ERP consultants get involved primarily throughout the implementation phase and could also be great support through the post-implementation stage. This support is an essential requirement while new functionalities or solutions are implemented and deployed. In line with the increase in the population of ERP consultations, the usefulness and value of consultants are still problematic (Markus et al., 2000). In fact, among the reported problems of consulting services, some significant ones include fast turnover, the interruption of services, the lack of balance and proportion of information and problems of honest communication caused by assigning authority to strangers (Markus et al., 2000). Therefore, the following preposition is formulated:

P2: ERP external consultants have positive effect on ERP post-implementation success.

ERP External Trust Influence PIS of ERP

Trust is defined as a key factor in a long lasting and successful supply chain relationship in inter business interactions and is becoming a more crucial element due to its involvement in a high level of interdependency (Mayer et al., 1995). Therefore, trust between business units plays an important role in ERP, as ERP is also considered a back bone to facilitate supply chain management. Even though some approaches on trust are evaluated in previous literature, this study develops a conceptual framework, which considers qualification and conventional trust between the supplier, customer, and ERP focal company. The importance of trust in the economy of business relationships is that it reduces the supervision of detailed agreements, as well as reduces transaction costs (Gulati, 1995). Hence, the effect of trust is that companies are convinced that a partner company will carry out procedures that will lead to positive results for the 
company, as well as preventing unforeseen outcomes that result in negative results (Anderson and Weitz, 1989). Therefore, a high level of trust will enable the company to investigate new beneficial preparations associated with the ERP post-implementation activities that develop inter-firm relationship (Hart and Saunders, 1997).

Trust is discussed often in the previous studies and in a variety of disciplines i.e., psychological, management, economics and sociological. This means that a lot is known about trust as a concept. Nevertheless, this also creates confusion about what should be considered as dimensions of trust (van Meurs et al., 2012). Both externally and internally, trust is the essential building block of organizational success. Because of this important position, it is vital for ERP professionals to analyze, manage and examine trust. Trust is a critical managerial tool that stimulates performance and commitment. Customer and supplier trust in this study are defined as a triadic group of trust, which included a focal organization, the supplier who supplies all manufacturing resources (i.e., row material, device, service etc.) and the customers which have interaction with the focal organization and ERP (Adam and Sammon, 2004). Additionally, this study looked at the trust of the customers and suppliers to the organization and the ERP system and vice versa.

The importance of trust of the customer and supplier to the ERP program in post stage is part of the important driving force, which previous ERP post-implementation success researches have missed to address. Therefore, trust between the supplier, customer and ERP system itself is crucial for applicant and system protection and is one of the most important critical factors. Even though past literature briefly mention the significance of dealings between employees and applicants in a company throughout ERP application (Amoako-Gyampah and Salam, 2004), theoretical infrastructures i.e., social capital theory briefly discuss the crucial role of trust in the personal and an organizational stage to obtain spirited benefits. Few studies examine trust through the all ERP area, as well as trust of an organization like supplier or customer with the ERP.

This study concentrate on the trust across the all level of participant in ERP solution, the trust between customers and suppliers to the focal company and its ERP and the trust between the company and its customers and suppliers in order to evaluate their impact on ERP success in order to gain benefits of ERP. Therefore, this study intends to investigate the following:

P3: ERP external trust has positive effect on ERP post-implementation success.

\section{Methodology to Validation of Conceptual Model}

This study provides a conceptual model for both scholars and professionals that represent environmental CSFs through applying the TOE framework to ERP post-implementation success. Also, this study adds to the body of knowledge by improving a conceptual model with strong supported by theory that contains an assortment of CSFs that some of their relationship with PIS of ERP under the support of TOE have not been empirically validated yet. In particular, this study serves to prepare researchers approaching the critical factors that have not been examined in past studies, especially ERP external trust. The study prepared practitioners with a theoretically validated conceptual framework that described recognized environmental critical factors that practitioners can leverage them for optimizing ERP post-implementation benefits. In other words, this research paper only completes a primary level by preparing an optimum theoretical validated model for optimization ERP PIS and examines these relationships assigned to other researchers.

Following the methodology successfully used in previous related papers (Gunasekaran and Ngai, 2005; Van der Vaart and van Donk, 2008) this study reviews prior research publications. The logic of established relationship between variables in the conceptual framework be elaborated by discussing characteristics of proposed model with other previous ERP post-implementation success literatures. Further analysis, justifications and supporting literature about theoretical underpinning of each variable in the proposed model is bring and shown in Table 1. This study analyzed research papers through the fifteen years in ERP post-implementation success from 2000 to 2015 and the most significant and related papers are selected and as described in Table3, by searching the key names of "ERP post-implementation success", "ERP post-implementation benefits" and "ERP critical success factors". After comprehensive discussion of each characteristic the proposed model of this study is presented in figure 1.

\section{Contribution}

This research paper propose a new approach to TOE theory by highlights the important roles of some new environmental antecedents of ERP post-implementation success. Therefore, this study introduced new environmental factors (i.e., external trust) to shed new light to the body of knowledge about the role of environmental factors in the effective implementation and maintaining of ERP in post implementation stage. In summary, this study makes several contributions to the ERP community. First, it contributes to the ERP researches by examining the effect of ERP external 
factors' critical factors on ERP post- implementation benefits. Second, it contributes to TOE theory by theoretically showing that ERP external pressure, ERP consultant support, and external trust are more powerful environmental critical resources to improving ERP benefits. The findings of the study illustrate that firms can leverage CSFs to improve success of ERP in post-implementation stage in order to receive expected benefits. Furthermore, the outcomes demonstrate that different critical success factors may have different effects on ERP benefits; extending the common statement of TOE theory that resources bring competitive advantages. Third, this study contributes to the ERP studies by exhibiting additional evidence of the different effects of CSFs on ERP post-implementation success.

In addition, this research paper can guide the practitioner by propose applicable method in order to promote ERP post-implementation success and present what they need to care during and after their ERP implementation. Then it could motivate them in conduct their post-implementation efforts more effective. Likewise, practitioners whom experienced collapse in their ERP post-implementation activities and have struggle with post-implementation difficult situation can have a much better reaction to come out with its difficulty to speed up the value creation of the ERP and the achievement of its benefits.

\section{Limitations and Future Recommendations}

The proposed research framework and established relationship between their variables in this research paper do not yet empirically examined. This is the first time that this study offers an established environmental CSFs framework for ERP PIS with exhibiting ERP external trust as a major missed to consider variable, while further researches in the future to examine proposed relationships is suggested. Examination these relationships in the near future will confirm the validation of the proposed model and its related introduced variables. Additional, often studies more preferred to introduce a list of CSFs in different phases and context of ERP and examine their relationships with PIS of ERP, while there are still more rooms to study the antecedent of presented CSFs and the impact of CSF's on other CSF's. The study by Schniederjans and Yadav (2013) proposed comprehensive model for ERP implementation success based on TOE framework and introduce trust as a new dimension for implementation stage. However, there is still lack of empirical examination of this model. The lack of research on trust and ERP post-implementation success is the main motivation of the study, but this study suggests that future research should investigate about antecedent factors that may impacts trust between the user, supplier, customer, and the system beside empirically examine the impact of ERP external trust on ERP post-implementation success. Furthermore, is there any mediator or moderator variable that can explain or effect the relationships between established CSFs and PIS of ERP. There are numerous questions remain unanswered. The researchers hope that other scholars will integrate these ideas to promote knowledge of ERP post- implementation.

\section{Conclusion}

Literatures in the area of critical success factors and ERP mostly presented and developed a list of CSFs, without studying how well one CSF can affect another or affect Performance and vice versa (Akkermans and van Helden, 2002; Kouki et al., 2010). The writers of this study suggest that further studies should keep away from restricted perspective to ERP CSFs that break ERP post-implementation CSFs to the small components that is partial and prepare a greater perception of ERP post-implementation by applying a comprehensive point of view that cover up all ERP postimplementation success issues. This study with respect to at least 2 decade of studying on ERP CSFs and ERP implementation success supports further study concentrating on approaches that have lacked or missed. Theoretical supports has provided for the justification of each external factors of external pressure, external consultant and external trust in ERP post-implementation. Hence, new research room is need to open on trust before and during ERP implementation, i.e., trust through all organizations involve in ERP, external consultants that support and maintains the ERP and trust to the ERP itself. The study hopes that the model proposed here can be applied as an instrument for optimizing ERP post-implementation. Overall, scholars can employ this conceptual model to add separate components into their research. The authors of this research paper support further empirical studies using the model in future research publications.

\section{References}

Abdullah, N. A. H. N. (2009). The Role Of Technology Attributes, Trust And Dependency On E-Procuremnt Adoptions: An Empirical Analysis Of Malaysian Manufacturers. University of Southern Queensland.

Adam, F. and Sammon, D. (2004). The Enterprise Resource Planning Decade: Lessons Learned And Issues For The Future. IGI Global. 
Akkermans, H. and van Helden, K. (2002). Vicious And Virtuous Cycles In ERP Implementation: A Case Study Of Interrelations Between Critical Success Factors. European Journal of Information Systems. 11(1), pp. 35-46.

Al-Mashari, M., Al-Mudimigh, A. and Zairi, M. (2003). Enterprise Resource Planning: A Taxonomy Of Critical Factors. European journal of operational research. 146(2), pp. 352-364.

Amoako-Gyampah, K. and Salam, A. F. (2004). An Extension Of The Technology Acceptance Model In An ERP Implementation Environment. Information \& Management. 41(6), pp. 731-745.

Anderson, E. and Weitz, B. (1989). Determinants Of Continuity In Conventional Industrial Channel Dyads. Marketing Science. 8(4), pp. 310-323.

Annamalai, C. and Ramayah, T. (2011). Enterprise Resource Planning (ERP) Benefits Survey Of Indian Manufacturing Firms: An Empirical Analysis Of SAP Versus Oracle Package. Business Process Management Journal. 17(3), pp. 495-509.

Barney, J. B. (1996). The Resource-Based Theory Of The Firm. Organization science. 7, pp. 469-469.

Basu, V. and Lederer, A. (2011). Agency Theory And Consultant Management In Enterprise Resource Planning Systems Implementation. ACM SIGMIS Database. 42(3), pp. 10-33.

Benders, J., Batenburg, R. and Van der Blonk, H. (2006). Sticking To Standards; Technical And Other Isomorphic Pressures In Deploying ERP-Systems. Information \& Management. 43(2), pp. 194-203.

Bradford, M. and Florin, J. (2003). Examining The Role Of Innovation Diffusion Factors On The Implementation Success Of Enterprise Resource Planning Systems. International Journal of Accounting Information Systems. 4(3), pp. 205-225.

Carey, S. and Lawson, B. (2011). Governance And Social Capital Formation In Buyer-Supplier Relationships. Journal of Manufacturing Technology Management. 22(2), pp. 152-170.

Davenport, T. and Linder, J. (1994). Information Management Infrastructure: The New Competitive Weapon? Proceedings of the System Sciences, 1994. Proceedings of the Twenty-Seventh Hawaii International Conference on. pp. 885-896.

DiMaggio, P. J. (1988). Interest And Agency In Institutional Theory. Institutional patterns and organizations: Culture and environment. 1, pp. 3-22.

DiMaggio, P. J. and Powell, W. W. (1983). And Collective Rationality In Organizational Fields. American Sociological Review. 48(2), pp. 147-160.

Esteves, J. (2009). A Benefits Realisation Road-Map Framework For ERP Usage In Small And Medium-Sized Enterprises. Journal of Enterprise Information Management. 22(1/2), pp. 25-35.

Gefen, D. (2004). What Makes An ERP Implementation Relationship Worthwhile: Linking Trust Mechanisms And ERP Usefulness. Journal of Management Information Systems. 21(1), pp. 263-288.

Grabski, S. V., Leech, S. A. and Schmidt, P. J. (2011). A review of ERP research: A future agenda for accounting information systems. Journal of Information Systems. 25(1), pp. 37-78.

Gulati, R. (1995). Does Familiarity Breed Trust? The Implications Of Repeated Ties For Contractual Choice In Alliances. Academy of management journal. 38(1), pp. 85-112.

Gunasekaran, A. and Ngai, E. W. (2005). Build-To-Order Supply Chain Management: A Literature Review And Framework For Development. Journal of operations management. 23(5), pp. 423-451.

Hart, P. and Saunders, C. (1997). Power And Trust: Critical Factors In The Adoption And Use Of Electronic Data Interchange. Organization science. 8(1), pp. 23-42.

Heider, F. (2013). The psychology of interpersonal relations. Psychology Press.

Hillman Willis, T. and Hillary Willis-Brown, A. (2002). Extending The Value Of ERP. Industrial Management \& Data Systems. 102(1), pp. 35-38.

Ifinedo, P., Rapp, B., Ifinedo, A. and Sundberg, K. (2010). Relationships Among ERP Post-Implementation Success Constructs: An Analysis At The Organizational Level. Computers in Human Behavior. 26(5), pp. 1136-1148.

Kamhawi, E. M. (2008). Enterprise Resource-Planning Systems Adoption In Bahrain: Motives, Benefits, And Barriers. Journal of Enterprise Information Management. 21(3), pp. 310-334.

Kouki, R., Pellerin, R. and Poulin, D. (2007). Going beyond ERP implementation: An ERP assimilation cross-case analysis. CIRRELT.

Kouki, R., Poulin, D. and Pellerin, R. (2010). The Impact Of Contextual Factors On ERP Assimilation: Exploratory Findings From A Developed And A Developing Country. Journal of global information technology management. 13(1), pp. 28-55.

Kronbichler, S. A., Ostermann, H., Rol, R. and Staudinger, S. (2009). A Review Of Critical Success Factors For ERP-Projects. Open Information Systems Journal. 3, pp. 14-25.

Law, C. C., Chen, C. C. and Wu, B. J. (2010). Managing The Full ERP Life-Cycle: Considerations Of Maintenance And Support Requirements And IT Governance Practice As Integral Elements Of The Formula For Successful ERP Adoption. Computers in Industry. 61(3), pp. 297-308.

Maak, T. (2007). Responsible Leadership, Stakeholder Engagement, And The Emergence Of Social Capital. Journal of Business Ethics. 74(4), pp. 329-343.

Markus, M. L., Axline, S., Petrie, D. and Tanis, S. C. (2000). Learning From Adopters' Experiences With ERP: Problems Encountered And Success Achieved. Journal of information technology. 15(4), pp. 245-265.

Mayer, R. C., Davis, J. H. and Schoorman, F. D. (1995). An Integrative Model Of Organizational Trust. Academy of management review. 20(3), pp. 709-734.

Nahapiet, J. and Ghoshal, S. (1998). Social Capital, Intellectual Capital, And The Organizational Advantage. Academy of management review. 23(2), pp. 242-266. 
Nejib, B. M. (2013). Determinants of Post Implementation Success of ERP In Tunisian Companies: An Empirical Study of The Moderating Role of The Technical Fit. International Review of Management and Business Research. 2(4), p. 1101.

Ononiwu, C. G. (2013). A Delphi Examination of Inhibitors of The Effective use of Process Industry Enterprise Resource Planning (Erp) Systems: A Case Study of New Zealand's Process Industry. Electronic Journal of Information Systems Evaluation. 16(2).

Pan, M.-J. and Jang, W.-Y. (2008). Determinants Of The Adoption Of Enterprise Resource Planning Within The TechnologyOrganization-Environment Framework: Taiwan's Communications Industry. Journal of Computer information systems. 48(3).

Paradice, D. (2009). Emerging Systems Approaches in Information Technologies: Concepts, Theories, and Applications: Concepts, Theories, and Applications. IGI Global.

Peng, M. W., Sun, S. L., Pinkham, B. and Chen, H. (2009). The Institution-Based View as a Third Leg for a Strategy Tripod. The Academy of Management Perspectives. 23(3), pp. 63-81.

Raymond, L., Uwizeyemungu, S. and Bergeron, F. (2006). Motivations To Implement ERP In E-Government: An Analysis From Success Stories. Electronic Government, an International Journal. 3(3), pp. 225-240.

Schniederjans, D. and Yadav, S. (2013). Successful ERP Implementation: An Integrative Model. Business Process Management Journal. 19(2), pp. 364-398.

Scott, W. R. (2008). Institutions and organizations: Ideas and interests. Sage.

Sedera, D. and Gable, G. G. (2004). A Factor And Structural Equation Analysis Of The Enterprise Systems Success Measurement Model. Proceedings of.

Shang, S. and Seddon, P. B. (2003). A Comprehensive Framework For Assessing And Managing The Benefits Of Enterprise Systems: The Business Manager's Perspective. Second-wave Enterprise Resource Planning Systems: Implementing for Effectiveness, Cambridge University Press, UK. pp. 75-101.

Shao, Z., Feng, Y. and Liu, L. (2012). The Mediating Effect Of Organizational Culture And Knowledge Sharing On Transformational Leadership And Enterprise Resource Planning Systems Success: An Empirical Study In China. Computers in Human Behavior. 28(6), pp. 2400-2413.

Shaul, L. and Tauber, D. (2013). Critical Success Factors In Enterprise Resource Planning Systems: Review Of The Last Decade. ACM Computing Surveys (CSUR). 45(4), p. 55.

Somers, T. M. and Nelson, K. G. (2004). A Taxonomy Of Players And Activities Across The ERP Project Life Cycle. Information \& Management. 41(3), pp. 257-278.

Spathis, C. and Ananiadis, J. (2005). Assessing The Benefits Of Using An Enterprise System In Accounting Information And Management. Journal of Enterprise Information Management. 18(2), pp. 195-210.

Supramaniam, M. and Kuppusamy, M. (2011). Investigating The Critical Factors In Implementing Enterprise Resource Planning System In Malaysian Business Firms. EJISDC: The Electronic Journal on Information Systems in Developing Countries. (46), p. 5.

Tarhini, A., Ammar, H. and Tarhini, T. (2015). Analysis Of The Critical Success Factors For Enterprise Resource Planning Implementation From Stakeholders' Perspective: A systematic review. International Business Research. 8(4), p. p25.

Teo, H.-H., Wei, K. K. and Benbasat, I. (2003). Predicting Intention To Adopt Interorganizational Linkages: An Institutional Perspective. Mis Quarterly. pp. 19-49.

Upadhyay, P., Jahanyan, S. and Dan, P. K. (2011). Factors Influencing ERP Implementation In Indian Manufacturing Organisations: A study of micro, small and medium-scale enterprises. Journal of Enterprise Information Management. 24(2), pp. 130-145.

Van der Vaart, T. and van Donk, D. P. (2008). A Critical Review Of Survey-Based Research In Supply Chain Integration. International Journal of Production Economics. 111(1), pp. 42-55.

van Meurs, I., van Ginkel, W. and van Oosterhout, M. (2012). An Agile Organization: The Influence Of Trust And Empowerment On The Agility Of An Organization. Erasmus Universiteit.

White, R. E. (2008). Post-Implementation Evaluation Of Enterprise Resource Planning (ERP) Systems. University of North Texas.

Wilson, C. V. (2012). Postimplementation Planning And Organizational Structure Of Enterprise Resource Planning Systems. Walden University.

Worrell, J. L. (2008). Running The ERP Marathon: Enhancing ERP-Business Fit In The Post-Implementation Phase. ProQuest.

Yang, C. and Su, Y.-f. (2009). The Relationship Between Benefits Of Erp Systems Implementation And Its Impacts On Firm Performance Of SCM. Journal of Enterprise Information Management. 22(6), pp. 722-752.

Yusuf, Y., Gunasekaran, A. and Abthorpe, M. S. (2004). Enterprise Information Systems Project Implementation:: A Case Study Of ERP In Rolls-Royce. International Journal of Production Economics. 87(3), pp. 251-266.

Zhu, K. (2004). The Complementarity Of Information Technology Infrastructure And E-Commerce Capability: A Resource-Based Assessment Of Their Business Value. Journal of Management Information Systems. 21(1), pp. 167-202.

Zhu, K., Kraemer, K. and Xu, S. (2003). Electronic Business Adoption By European Firms: A Cross-Country Assessment Of The Facilitators And Inhibitors. European Journal of Information Systems. 12(4), pp. 251-268.

Zhu, K. and Kraemer, K. L. (2005). Post-Adoption Variations In Usage And Value Of E-Business By Organizations: Cross-Country Evidence From The Retail Industry. Information Systems Research. 16(1), pp. 61-84.

Zhu, K., Kraemer, K. L. and Dedrick, J. (2004). Information Technology Payoff In E-Business Environments: An International Perspective On Value Creation Of E-Business In The Financial Services Industry. Journal of Management Information Systems. 21(1), pp. 17-54.

Zhu, Y., Li, Y., Wang, W. and Chen, J. (2010). What Leads To Post-Implementation Success Of ERP? An Empirical Study Of The Chinese Retail Industry. International Journal of Information Management. 30(3), pp. 265-276. 